\title{
Population structure and breeding period of Pachycheles monilifer (Dana) (Anomura, Porcellanidae) inhabiting sabellariid sand reefs from the littoral coast of São Paulo State, Brazil
}

\author{
Adilson Fransozo 1 \\ Giovana Bertini $^{1}$
}

\begin{abstract}
The purpose of the present study is to examine the population structure and the breeding period of Pachycheles monilifer (Dana, 1852) inhabiting sabellariid worm reefs in the littoral of São Paulo State coast. The specimens were obtained at 2-month intervals from September/94 to July/95. The study sites were located at the rocky shores of Tenório and Paranapuã Beaches. Individuals sampled showed a total averaged $4.4 \pm 1.4 \mathrm{~mm}$ carapace length. Ovigerous females were more frequent in September. Despite clear differences regarding the arrangement of these sabellariid colonies, they are extremely important to the establishment and maintenance of $P$. monilifer.

KEY WORDS. Porcellanidae, Pachycheles monilifer, sabellariid worm reefs, biology
\end{abstract}

According to MELO (1999), porcelain crabs enclose 27 genera and about 230 species, among which 21 are found in Brazil and 13 along São Paulo State coast. Porcelain crabs are much alike true (brachyuran) crabs, but they possess uropods and their reduced last walking legs are dorsally directed. The Porcellanidae are mainly represented by littoral species, excepting rare accounts in the deep sea. They are known to occupy a variety of habitats, including hard substrata such as crevice systems, under boulders or in bottoms covered by calcareous algae (VELOSO \& MELO 1993).

In general, sabellariid polychaetes build up conspicuous masses of sandcompacted tubes, forming extensive colonies composed by thousands of individuals (AMARAL 1987).

These reefs supply a hard substratum, shelter and food for several decapod species allowing them to exploit the surf zone; an area probably inaccessible otherwise (GORE et al. 1978). Some studies had focused the composition, biology and the interaction among decapod crustaceans associated to sabellariid worm reefs (e.g Fausto-Filho \& FURTAdo 1970; Gore et al. 1978; AlmaÇA 1990; PinHeIro et al. 1997; NEGREIROS-FRANSOZO et al. 1998; MiCHELETTI-FLORES \& NEGREIROS-FrANSOZO 1999). Other studies had emphasized the population structure and reproductive biology of porcelain crabs (SAMUELSEN 1970; SMALDON 1972; AHMED \& MustaQuim 1974; BREMEC \& CAZZANiga 1984; Scelzo 1985; STEVCIC 1985; OLIVEIRA \& MASUNARI 1995).

1) Departamento de Zoologia, Instituto de Biociências, Universidade Estadual Paulista. Caixa Postal 510, 18618-000 Botucatu, São Paulo, Brazil. E-mail: fransozo@ibb.unesp.br 
The porcelain crab Pachycheles monilifer (Dana, 1852) is distributed along the Western Atlantic coast from Eastern coast of Florida (USA) to Brazil (from Rio Grande do Norte to Santa Catarina), including Gulf of Mexico and Venezuela. It was also found in Eastern Pacific (Equador) by Veloso \& MELO (1993).

The purpose of the present study is to examine the population structure and the reproductive period of $P$. monilifer inhabiting sabellariid worm reefs from littoral of São Paulo State coast.

\section{MATERIAL AND METHODS}

The individuals of $P$. monilifer were obtained at 2-month intervals from September/1994 to July/1995 in Tenório Beach, Ubatuba (23⒉ $28^{\prime} \mathrm{S}$ and $\left.45^{\circ} 03^{\prime} \mathrm{W}\right)$

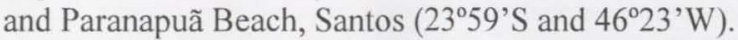

The sample size was determined by a performance curve (BROWER \& ZAR 1977 ) and the mean size of each sample for each beach was approximately $50 \mathrm{~kg}$.

At the laboratory, porcelain crabs were sorted and fixed in $10 \%$ formaline. They were sexed and their carapace length (CL) measured with the aid of a microscope provided with a camera lucida. Females present gonopores in the coxa of the third pair of pereopods and three pleopod pairs located at the $3^{\text {rd }}, 4^{\text {th }}$ and $5^{\text {th }}$ abdominal somites. Males are characterized by lacking pleopods. Individuals smaller than $2.5 \mathrm{~mm}$ of CL were classified as "non-sexable" specimens (ns).

In size frequency distribution individuals were separated in four categories: males, adult non-ovigerous females, ovigerous females and non-sexable individuals. Performing $95 \%$ confidence intervals tested differences of crab size between populations and sexes.

\section{RESULTS}

During the sampling period, 157 P. monilifer specimens were obtained at Tenório and Paranapuã Beaches. Table I shows the number total of individuals of each category obtained during this study.

Table I. Pachycheles monilifer. Total number of individuals obtained at each month during the sampling period (September/94 to July/95).

\begin{tabular}{lcccccc}
\hline \multicolumn{1}{c}{ Months } & ns & Males & Non-ovigerous females & Ovigerous females & Total of individuals & Total (\%) \\
\hline September & - & 4 & 2 & 8 & 14 & 8.9 \\
November & 3 & - & 2 & - & - & - \\
January & - & - & 6 & 5 & 28 & - \\
March & 1 & 16 & 3 & 5 & 11 & 7.8 \\
May & - & 3 & 28 & 19 & 99 & 63.1 \\
July & 8 & 44 & 41 & 37 & 157 & 100.0 \\
\hline Total & 12 & 67 & &
\end{tabular}

Amplitudes and mean values are shown in table II for each category. No significant difference was found between size of individuals in both populations and between sex $(p>0.05)$.

A total of 11 size classes starting at $1.1 \mathrm{~mm} \mathrm{CL}$ with an interval of $0.7 \mathrm{~mm}$ were used. Non-sexable crabs were distributed in the first two size-classes, while 
juveniles with already noticeable secondary sexual characters fell in the third one. In the case of ovigerous females, size-range was restricted from the $4^{\text {th }}$ to the $9^{\text {th }}$ size classes (Fig. 1).

Ovigery proportion from potential breeding females varied along the sampling period with a highest number of ovigerous females were obtained in September. In November and January no ovigerous females were recorded (Fig. 2).

Table II. Pachycheles monilifer. Descriptive statistics of carapace length $(\mathrm{mm})$ in each category.

\begin{tabular}{lcccc}
\hline \multicolumn{1}{c}{ Sex } & N & Mean \pm sd & Minimum & Maximum \\
\hline Non-sexable & 12 & $2.0 \pm 0.3$ & 1.6 & 2.5 \\
Males & 67 & $4.6 \pm 1.3$ & 2.6 & 8.5 \\
Non-ovigerous females & 41 & $3.9 \pm 1.1$ & 2.6 & 7.6 \\
Ovigerous females & 37 & $5.3 \pm 1.0$ & 3.3 & 7.3 \\
\hline
\end{tabular}

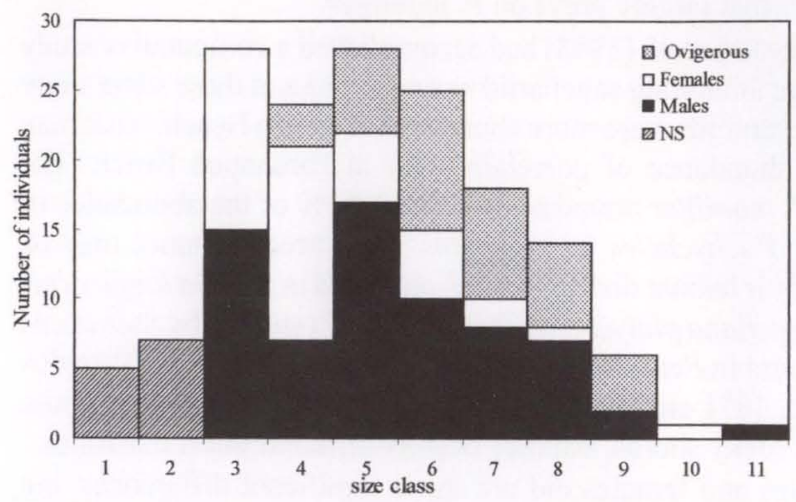

$\begin{array}{cc}\text { Size Classes } & \text { CL (mm) } \\ 1 & 1.1-] 1.8 \\ 2 & 1.8-\mathrm{]} 2.5 \\ 3 & 2.5-\mathrm{j} 3.2 \\ 4 & 3.2-\mathrm{]} 3.9 \\ 5 & 3.9-\mathrm{]} 4.6 \\ 6 & 4.6-\mathrm{]} 5.3 \\ 7 & 5.3-\mathrm{]} 6.0 \\ 8 & 6.0-\mathrm{]} 6.7 \\ 9 & 6.7-\mathrm{]} 7.4 \\ 10 & 7.4-\mathrm{]} 8.1 \\ 11 & 8.1-\mathrm{]} 8.8\end{array}$

Fig. 1. Pachycheles monilifer. Size-frequency distributions for crabs sampled.

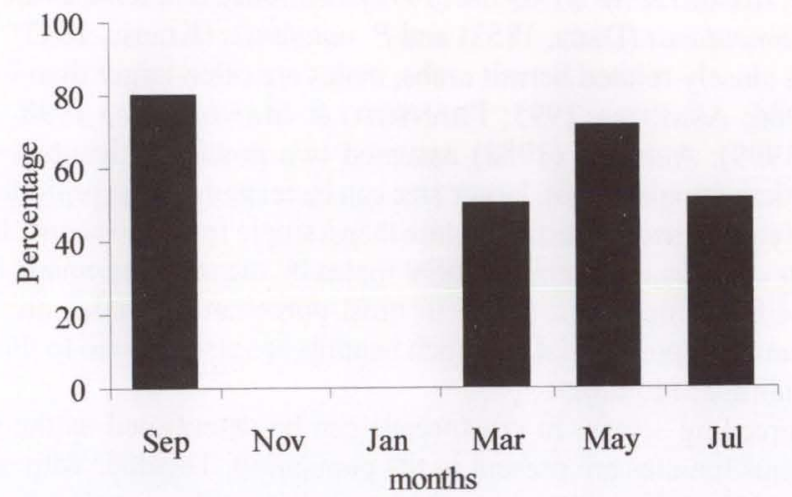

Fig. 2. Pachycheles monilifer. Percentage of ovigerous females of all potential breeding individuals. 


\section{DISCUSSION}

The Paranapuã Beach is a much more sheltered environment than Tenório Beach, besides the former is more exposed to a high concentration of pollutants that may probably contribute to the development of Phragmatopoma lapidosa Kinberg, 1867 colonies. This fact benefits several other species that depend on this sabellariid polychaet at least during a certain life-phase.

Besides clear differences regarding the arrangement of these sabellariid colonies, they are extremely important to the establishment and maintenance of $P$. monilifer at both sites. According to GoRE et al. (1978), the porcelain crab $P$. monilifer feeds on suspension organic matter and seeks for shelter in these sand reefs to avoid predators. Therefore, its trophic level is similar to its host's, only differing in the size of ingested particles. The authors also stated that a variety of crab species inhabiting these colonies are predators, as is the case of Menippe nodifrons Stimpson, 1859 that largely preys on $P$. monilifer.

NEGREIROS-FRANSOZO et al. (1998) had accomplished a comparative study of the decapod assemblage inhabiting sabellariid worm colonies at these same study sites. They observed that xanthids were more abundant at Tenório Beach, what may also explain the higher abundance of porcelain crabs at Paranapuã Beach. The authors had found that $P$. monilifer abundance was about $1 \%$ of the abundance of the co-existing congener Pachycheles laevidactylus. Such predominance may be related to differences in their habitat distribution, as observed in Pisidia longicornis (Linnaeus, 1766) and Porcellana platycheles (Pennant, 1777) studied by SMALDOM (1972) and SANZ (1987) and in Petrolisthes cinctipes (Randall, 1861) and Petrolisthes eriomerus Stimpson, 1871 studied by JENSEN \& ARMSTRONG (1991). Those sympatric species live in rocky shores, but they occupy different intertidal zones.

Mean size of males and females did not show significant differences, but males attained a larger size. Similar results were reported for the porcellanid genera Petrolisthes by JONES (1977), SCELzo (1985) and OLIVEIRA \& MASUNARI (1995), and for Porcellana and Pisidia by SMALDON (1972) and SANZ (1987). For the genus Pachycheles, AHMED \& MUSTAQUIM (1974) mentioned that females are larger than males in P. tomentosus (Dana, 1852) and P. natalensis (Krauss, 1843).

In the closely related hermit crabs, males are often larger than females (e.g. HAZLETT 1966; ASAKURA 1995; FRANSOZO \& MANTELATTO 1998; BERTINI \& FRANSOZO 1999). ABRAMS (1988) assumed two possible advantages for males being larger than females. First, larger size can be related to high reproductive effort in males, which can thereby fertilize more than a single female. Second, larger males increase their chances to obtain potential mates by means of agonistic interactions with conspecific competitors. Since in most porcellanids, males are larger than females, it can be hypothesized that such benefits are also applied to this anomuran family, including P. monilifer.

The breeding season in crustaceans can be determined as the year-period when ovigerous females are present in the population. Together with other related topics such as fecundity, larval dynamics and juvenile-megalopal recruitment, information on the breeding patterns of dominant species is of most importance towards a better understanding of their reproductive biology (EMMERSON 1994). 
As can been seen in table III porcellanids already studied had shown a great variability of reproductive patterns. Ovigerous females of $P$. monilifer were not recorded in the population only during summer, indicating that this species have a wide reproductive period.

Table III. Breeding period in some porcellanid species.

\begin{tabular}{|c|c|c|c|}
\hline Species & Breeding period & Geographic location & Reference \\
\hline Petrolisthes politus (Gray, 1831) & Year-round & $\begin{array}{l}\text { Isla Cubagua, Venezuela } \\
\left(10^{\circ} \mathrm{N}\right)\end{array}$ & SCELZO (1985) \\
\hline Petrolisthes boscii (Audovim, 1826) & Feb-Oct & $\begin{array}{l}\text { Manora Island, Karachi, } \\
\text { Pakistan }\left(24^{\circ} \mathrm{N}\right)\end{array}$ & $\begin{array}{l}\text { AHMED \& MUSTAQUIM } \\
(1974)\end{array}$ \\
\hline Petrolisthes cinctipes (Randall, 1839) & Year-round & $\begin{array}{l}\text { Monterey Bay, California, } \\
\text { USA }\left(36^{\circ} \mathrm{N}\right)\end{array}$ & $\begin{array}{l}\text { BOOLOOTIAN et al. } \\
\text { (1959) }\end{array}$ \\
\hline Petrolisthes rufescens (Heller, 1861) & Jan - Nov & $\begin{array}{l}\text { Manora Island, Karachi, } \\
\text { Pakistan }\left(24^{\circ} \mathrm{N}\right)\end{array}$ & $\begin{array}{l}\text { AHMED \& MUSTAQUIM } \\
\text { (1974) }\end{array}$ \\
\hline Petrolisthes armatus (Gibbes, 1850) & Year-round & $\begin{array}{l}\text { Ilha do Farol, Paraná, Brazil } \\
\left(25^{\circ} \mathrm{S}\right)\end{array}$ & $\begin{array}{l}\text { OLIVEIRA \& MASUNARI } \\
\text { (1995) }\end{array}$ \\
\hline Petrolisthes elongatus ( $\mathrm{H}$. Milne Edwards, 1837) & Year-round & $\begin{array}{l}\text { Hauraki Gulf, New Zeland } \\
\left(37^{\circ} \mathrm{S}\right)\end{array}$ & GREENWOOD (1965) \\
\hline Petrolisthes elongatus ( $\mathrm{H}$. Milne Edwards, 1837) & Jul - Mar & $\begin{array}{l}\text { Wellington Harbour, New } \\
\text { Zeland }\left(41^{\circ} \mathrm{S}\right)\end{array}$ & WEAR (1965) \\
\hline Petrolisthes elongatus ( $\mathrm{H}$. Milne Edwards, 1837) & Oct - Mar & $\begin{array}{l}\text { Kaikoura Peninsula, New } \\
\text { Zeland }\left(42^{\circ} \mathrm{S}\right)\end{array}$ & JONES (1977) \\
\hline Petrolisthes novazelandiae (Haig, 1981) & Year-round & $\begin{array}{l}\text { Wellington Harbour, New } \\
\text { Zeland }\left(41^{\circ} \mathrm{S}\right)\end{array}$ & WEAR (1964) \\
\hline Petrolisthes eriomerus Haig, 1956 & 8 months & $\begin{array}{l}\text { Puget Sound, Washington, } \\
\text { USA }\left(49^{\circ} \mathrm{N}\right)\end{array}$ & KNUDSEN (1964) \\
\hline Petrolisthes vanderhorsti Haig, 1956 & Apr-May & Barbados, West India $\left(13^{\circ} N\right)$ & LEWIS (1960) \\
\hline Pisidia longicornis (Linnaeus, 1766) & May-Oct & $\begin{array}{l}\text { Gower Peninsula, South } \\
\text { Wales, UK }\left(51^{\circ} \mathrm{N}\right)\end{array}$ & SMALDON (1972) \\
\hline Pisidia longicornis (Linnaeus, 1766) & May-Oct & $\begin{array}{l}\text { Raunefjorden, Western } \\
\text { Norway }\left(60^{\circ} \mathrm{N}\right)\end{array}$ & SAMUELSEN (1970) \\
\hline Porcellana platycheles (Pennant, 1777) & Mar-Aug & $\begin{array}{l}\text { Gower Peninsula, South } \\
\text { Wales, UK }\left(51^{\circ} \mathrm{N}\right)\end{array}$ & SMALDON (1972) \\
\hline Porcellana platycheles (Pennant, 1777) & Feb-Jun & $\begin{array}{l}\text { Ruja Bay, Northern Adriatic, } \\
\text { Croatia }\left(45^{\circ} \mathrm{N}\right)\end{array}$ & STEVCIC (1985) \\
\hline Porcellana platycheles (Pennant, 1777) & Jan-Aug & $\begin{array}{l}\text { Ericeira, Lisboa, Portugal } \\
\left(39^{\circ} \mathrm{N}\right)\end{array}$ & ALMAÇA (1990) \\
\hline Pachycheles tomentosus (Dana, 1852) & Year-round & $\begin{array}{l}\text { Manora Island, Karachi, } \\
\text { Pakistan }\left(24^{\circ} \mathrm{N}\right)\end{array}$ & $\begin{array}{l}\text { AHMED \& MUSTAQUIM } \\
(1974)\end{array}$ \\
\hline Pachycheles natalensis (Krauss, 1843) & Year-round & $\begin{array}{l}\text { Manora Island, Karachi, } \\
\text { Pakistan }\left(24^{\circ} \mathrm{N}\right)\end{array}$ & $\begin{array}{l}\text { AHMED \& MUSTAQUIM } \\
(1974)\end{array}$ \\
\hline Pachycheles monilifer (Dana, 1852) & Mar-Sept & \multicolumn{2}{|c|}{$\begin{array}{l}\text { Paranapuã and Tenório, Săo Present Study } \\
\text { Paulo, Brazil }\left(23^{\circ} \mathrm{S}\right)\end{array}$} \\
\hline
\end{tabular}

There are many opinions about the factors that regulate the reproductive period of marine crustaceans. AMEYAW-AKUMFI (1975) drew attention to the possibility of competition as a factor involved in the breeding of tropical hermit crabs. For SASTRY (1983) the breeding period seems to be closely related to temperature, food availability for larvae, and latitude where a given population is located. SCELZO (1985) suggested that the variation in the reproductive period is related to better temperatures for the species or periods of higher primary and/or secondary production providing higher availability of food to the planctonic larvae and to the deposit-feeders organisms.

Sabellariid worm reefs play a key role during the ontogeny of $P$. monilifer. The biologic processes of this species largely depend on an adequate development of the intertidal sabellariid biotope. 
ACKNOWLEDGMENTS. We are grateful to the "Fundação de Amparo à Pesquisa do Estado de São Paulo (FAPESP)" for financing transport to the collecting sites (\# 94/4878-8). We are also thankful to the NEBECC coworkers for their help during collection.

\section{REFERENCES}

ABRAMS, P.A. 1988. Sexual difference in resource use in hermit crabs; consequences and causes, p. 283-296. In: G. ChelAzZI \& M. VANNINI (Eds). Behavioural adaptations to the intertidal life. Plenum Press, New York, 575p.

ASAKURA, A. 1995. Sexual differences in life history and resource utilization by the hermit crab. Ecology 76 (7): 2295-2313.

AHMED, M. \& J. MusTAQuim. 1974. Population structure of four species of porcellanid crabs (Decapoda, Anomura) occurring on the coast of Karachi. Mar. Biol. 26: 173-182.

ALMAÇA, C. 1990. Structure and interactions in the crab community inhabiting sabelariid worm colonies at Praia de Ribeira D'Ilhas (Ericeira, Portugal). Arq. Museu Bocage, N.S. 1 (37): 505-519.

AmARAL, A.C.Z. 1987. Breve caracterização de Phragmatopoma lapidosa Kinberg, 1867 (Polychaeta, Sabellaridae). Revta bras. Zool. 3 (8): 471-474.

AMEYAW-AKUмFi, C. 1975. The breedinf biology of two sympatric species of tropical intertidal hermit crabs, Clibanarius chapini and C. senegalensis. Mar. Biol. 29: 15-28.

Bertini, G. \& A. Fransozo. 1999. Population dynamics of Petrochirus diogenes (Linnaeus, 1758) (Crustacea, Anomura, Diogenidae) in the Ubatuba region (SP), Brazil, p. 331-342. In: J.C.V.V. KLEIN \& F.R Schram (Eds). The Biodiversity Crisis and Crustacea, Crustacean Issues, 12. Rotterdam, A.A. Balkema, Brookfield, 848p.

Boolootian, R.A.; A.C. Giese; A. Farmanfarmaian \& J. Tucker. 1959. Reproductive cycles of five west coast crabs. Physiol. Zool. 32: 213-220.

BREMEC, C.S. \& N.J. CAZZANIGA. 1984. Consideraciones sobre Pachycheles haigae Rodrigues da Costa, 1960 y P. chubutensis Boschi, 1963 en Monte Hermoso (Repúplica Argentina) (Crustacea, Anomura, Porcellanidae). Iheringia, Sér. Zool., (64): 127-148.

BROWER, J.E. \& H. ZAR. 1977. Field and laboratory methods for general ecology. Dubuque, Wm. C. Brown publishers, 226p.

EMMERSON, W.D. 1994. Seasonal breeding cycles and sex ratios of eight species of crabs from Mgazana, a mangrove estuary in Tanskrei, Southem Africa. Jour. Crustacean. Biol. 14 (3): 568-578.

FAUSTO-FILHO, J. \& E. FURTADO. 1970. Nota preliminar sobre a fauna das colônias de Sabellariidae do litoral do Estado do Ceará (Annelida, Sedentaria). Rev. Brasil. Biol. 30 (2): 285-289.

Fransozo, A. \& F.L.M. MANTEL.ATTO. 1998. Population structure and reproductive period of the tropical hermit crab Calcinus tibicen (Decapoda, Diogenidae) in the Ubatuba region, São Paulo, Brazil. Jour. Crustacean. Biol. 18 (3): 446-452.

Gore, R.H.; L.E. SCOTTO \& L.J. BECKER. 1978. Community composition, stability, and trophic partitioning in decapod crustaceans inhabiting some subtropical sabelariid worm reefs. Bull. Mar. Sci. 28 (2): 221-248.

Greenwood, J.G. 1965. The larval development of Petrolisthes elongatus (H. Milne Edwards) and Petrolisthes novaezelandiae Filhol (Anomura, Porcellanidae) with notes on breeding. Crustaceana 8: 285-307.

Hazlett, B.A. 1966. Social behavior of the Paguridae and Diogenidae of Curaçao. Stud. Fauna Curaçao Other Caribb. Isl. 23 (88): 1-143.

JENSEN, G.C. \& D.A. ARMSTRong. 1991. Intertidal zonation among congeners: factors regulating distribution of porcelain crabs Petrolisthes spp. Mar. Ecol. Prog. Ser. 73: 47-60.

JONES, M.B. 1977. Breeding and seasonal population changes of Petrolisthes elongatus (Crustacea, Decapoda, Anomura) at Kaikoura, New Zeland. Jour. Royal Soc. N. Zealand. 7 (3): 259-272.

KNUDSEN, J.W. 1964. Observations of the reproductive cycles and ecology of the common Brachyura and crablike Anomura of Puget Sound, Washington. Pac. Sci. 18: 3-33. 
LEwIS, J.B. 1960. The fauna of rocky shores of Barbados, West Indies. Can. Jour. Zool. 38: 391-435.

MELo, G.A.S. 1999. Manual de identificação dos Crustacea Decapoda do litoral brasileiro: Anomura, Thalassinidea, Palinuridea e Astacidea. São Paulo, Editora Plêiade, 551p.

Micheletti-Flores, C.V. \& M.L. Negreiros-Fransozo. 1999. Porcellanid crabs (Crustacea, Decapoda) inhabiting sand reefs built by Phragmatopoma lapidosa (Polychaeta, Sabellariidae) at Paranapuã Beach, São Vicente, SP, Brazil. Rev. Brasil. Biol. 59 (1): 63-73.

Negreiros-Fransozo, M.L.; A.A.V. Flores; A.L.D. Reigada \& J.M. Nakagaki. 1998. Análise Comparativa dos Crustáceos Decápodos de Colônias de Sabellariidae em duas localidades do Litoral Paulista. An. IV Simp. Ecossist. Brasil. 2: 214-220.

Oliveira, E. \& S. MASUnARI. 1995. Estrutura populacional de Petrolisthes armatus (Gibbes) (Decapoda, Anomura, Porcellanidae) da Ilha do Farol, Matinhos, Paraná, Brasil. Revta bras. Zool. 12 (2): 355-371.

Pinheiro, M.A.A.; G. Bertini; L.C. Fernandes-Góes \& A. Fransozo. 1997. Decapod crustacean associated to sand reefs of Phragmatopoma lapidosa Kimberg, 1867 (Polychaeta, Sabellariidae) at Praia Grande, Ubatuba, SP, Brazil. Nauplius 5 (2): 77-83.

Samuel.Sen, T.J. 1970. The biology of six species of Anomura (Crustacea, Decapoda) from Raunefjorden, Westem Norway. Sarsia 45: 25-52.

SANZ, A. 1987. Notas sobre la biología de Porcellana platycheles (Pennant, 1777) (Anomura, Porcellanidae). Inv. Pesq. 51 (1): 117-124.

SASTRY, A.N. 1983. Ecological aspects of reproduction, p. 179-269. In: F.J. VernBERG \& W.B. VERNBERG (Eds). The biology of crustacea, 8. Enviromental adaptations. New York, Academic Press, 383p.

SCElzo, M.A. 1985. Biologia y morfometria del cancrejo Petrolisthes politus (Gray, 1831) (Anomura, Porcellanidae) de la Isla Cubagua, Venezuela. Bol. Inst. Oceanogr. Univ. Oriente 24 (1-2): 63-74

Smaldon, G. 1972. Population structure and breeding biology of Pisidia longicornis and Porcellana platycheles. Mar. Biol. 17: 171-179.

STEVCIC, Z. 1985. Autoecological investigations of the porcelain crab Porcellana platycheles (Pennant) (Decapoda, Anomura) in the Rovinj area (Northem Adriatic). Crustaceana 55 (3): 242-252.

Veloso, V.G. \& G.A.S. Melo. 1993. Taxonomia e distribuição da família Porcellanidae (Crustacea, Decapoda, Anomura) no litoral brasileiro. Iheringia, Sér. Zool., (75): 171-186.

WEAR, R.G. 1964. Larvae of Petrolisthes novaezelandiae Filhol, 1885 (Crustacea, Decapoda, Anomura). Trans. R. Soc. N. Zealand Zool. 5 (18): 229-244.

1965. Breeding cycles and pre-zoea larva of Petrolisthes elongatus (Milne Edwards, 1837).

(Crustacea, Decapoda). Trans. R. Soc. N. Zealand Zool. 5 (13): 169-175.

Recebido em 28.X.1999; aceito em 05.IV.2001. 